Іноземцева О.Б., к.держ.упр., ДСНС Украӥни, м. Київ, ORCID: 0000-0003-3764-0389

Inozemtseva O., PhD in Public Administration, Deputy Head of the Emergency Investigation Department, The State Emergency Service of Ukraine, Kyiv

\title{
ТЕОРЕТИЧНІ ЗАСАДИ ОЦІНЮВАННЯ КАДРОВОЇ ПОЛІТИКИ СЛУЖБИ ЦИВІЛЬНОГО ЗАХИСТУ
}

\section{THEORETICAL BASIS OF EVALUATION OF PERSONNEL POLICY OF THE CIVIL DEFENSE SERVICE}

У статті узагальнено теоретичні засади очінювання кадрової політики служби ичивільного захисту. Досліджено нормативно-правову базу, функиії ДСНС в галузі кадрової політики служби цииільного захисту. Виявлено певні проблеми кадрової політики системи ДСНС та запропоновано шляхи їх вирішення.

Ключові слова: кадрова політика, Державна служба України з надзвичайних ситуацій, служба циивільного захисту, управління персоналом, особи рядового та начальнищького складу служби иџивільного захисту.

The theoretical basis for assessing the personnel policy of the Civil Defense Service are summarized in the article. The SESU normative-legal base and functions in the field of personnel policy of the civil protection service are investigated. Some problems of personnel policy of the Civil Defense Service and perspectives of its solution are offered.

Key words: personnel policy, State Emergency Service of Ukraine, civil defense service, personnel management, ordinary and management staff of the civil defense service.

Постановка проблеми. Питання кадрової політики, розвитку персоналу було і залишається у даний час недостатньо вивченим. Воно розглядається не лише як економічна категорія, але і вивчається іншими науками, охоплює досить масштабну нішу в наукових дослідженнях та відіграє ключову роль у виробничій діяльності підприємств, установ та організацій на внутрішньому та зовнішньому ринках. Усе це визначає актуальність теми дослідження.

Мета статті - дослідити теоретичні засади оцінювання кадрової політики служби цивільного захисту.

Аналіз останніх досліджень і публікацій. Дослідженням теоретичних засад оцінювання кадрової політики служби цивільного захисту займались 
М.В. Данюк, В.П. Садковий, С.М. Домбровська, В.М. Петюх, С.П. Потеряйко, Д.В. Бондар, В.М. Шамраєва, А.В. Ромін, Я.Б. Зорій, В.О. Тищенко та інші.

Виклад основного матеріалу дослідження. Система розвитку персоналу кожного підприємства, установи чи організації $\epsilon$ його прерогативою для підвищення рівня рентабельності та досягнення високих ринкових позицій. За умов зростаючої ролі людського чинника у сучасному виробничому процесі, одним із найважливіших завдань сучасних систем управління є розвиток різноманітних здібностей працівників з метою забезпечення високого рівня конкурентоздатності та прибутковості вітчизняних суб'єктів господарювання. У зв'язку з цим, виникає потреба у розробці нових підходів до прийняття управлінських рішень, а також новітніх ефективних технологій, засобів і методів професійного розвитку персоналу підприємства, установи чи організації.

Основою системи підготовки кадрів для Державної служби України 3 надзвичайних ситуацій (далі - ДСНС) є система відомчої освіти ДСНС, що складається із навчальних закладів цивільного захисту та органів управління у складі апарату ДСНС. Структура освіти ДСНС включає вищу, професійнотехнічну та післядипломну.

Для підготовки фахівців відповідного ступеня вищої освіти для органів і підрозділів в ДСНС згідно зі статтею 11 Закону України «Про вищу освіту» [1] діє система вищої освіти, що становить: вищі навчальні заклади цивільного захисту (далі - ВН3); рівні і ступені вищої освіти; галузі знань i спеціальності; освітні і наукові програми; стандарти освітньої діяльності та стандарти вищої освіти; учасники освітнього процесу; органи управління освітою у складі апарату ДСНС.

У сучасних умовах основною складовою управління персоналом підприємства, установи, організації, діяльність яких пов'язана з організацією i здійсненням заходів цивільного захисту є створення умов для розширення знань, підвищення кваліфікації, безперервного самовдосконалення та саморозвитку працівників системи ДСНС. Особливого значення сьогодні набувають проблеми модернізації класичних систем менеджменту персоналу та впровадження нових моделей управління, орієнтованих на безперервний розвиток інтелектуального, культурного та творчого потенціалу працівників підприємств, установ, організацій, діяльність яких пов'язана з організацією і здійсненням заходів цивільного захисту.

Перспективи ефективності управлінської праці пов'язані з підвищенням ролі таких ресурсів, як знання та здібності. Збільшення останніх є одним із пріоритетних напрямів діяльності підприємств, установ, організацій, діяльність яких пов'язана з організацією і здійсненням заходів цивільного захисту. Сьогодні підготовку фахівців з вищою освітою для органів і підрозділів ДСНС здійснюють:

- Національний університет цивільного захисту України (далі - НУЦЗ 
України) та його відокремлений структурний підрозділ - Черкаський інститут пожежної безпеки імені Героїв Чорнобиля (далі - ЧІПБ);

- Львівський державний університет безпеки життєдіяльності (далі ЛДУБЖД).

Професійний добір керівних кадрів являє собою сукупність заходів щодо встановлення придатності тієї чи іншої особи до виконання завдань за призначенням, визначених управлінських обов'язків. Психологічна спрямованість, схильність особистості до різних видів трудової діяльності відіграють головну роль при доборі керівних кадрів. Тому насамперед слід вивчити ті риси характеру людини, ті особисті властивості, що безпосередньо впливають на результати діяльності керівника на певному робочому місці (посаді).

Відповідно до запитів територіальних органів ДСНС та аналізу отриманої інформації встановлено, що існує негативна практика призначення випускників вищих навчальних закладів ДСНС на посади, які не відповідають здобутим ними спеціальностям та освітнім ступеням. Так, наприклад, 46\% фахівців, яких було призначено на посаду начальника караулу (ступінь вищої освіти «бакалавр»), мали освітній ступень «спеціаліст» або «магістр». У той же час посада начальника караулу передбачає згідно з вимогою «Довідника кваліфікаційних характеристик професій ДСНС України» наявність стажу роботи у сфері цивільного захисту не менше 2 років.

Існують непоодинокі випадки призначення випускників, які здобули ступінь вищої освіти «бакалавр», на інженерні посади та на посади, що не відповідають напрямам підготовки, а саме - випускники, які отримали освіту за спеціальністю «Екологія», призначалися на посади фахівців відділів роботи з персоналом, начальників караулу, тощо; випускники, які отримали освіту за спеціальністю «Психологія», призначалися на посади начальників караулу, інженерів з аварійно-рятувальних робіт, інспекторів 3 нагляду та контролю у сфері пожежної безпеки тощо. Тому, у зв'язку з вищезазначеним необхідним $\epsilon$ визначення основних засад оцінювання кадрової політики служби цивільного захисту.

Сьогодні існує декілька критеріїв оцінки ефективності кадрової політики вцілому, однак, що стосується безпосередньо кадрової політики служби цивільного захисту, то, на мій погляд, слід зупинитись на трьох найважливіших:

1. Кількісний та якісний склад персоналу системи ДСНС:

- укомплектування системи ДСНС необхідною кількістю персоналу певних професій, спеціальностей, кваліфікації за: рівнем загальної і спеціальної освіти; середнім віком працівників; статтю; стажем роботи / вислугою років за даною спеціальністю (на посаді) і стажем роботи / вислугою років у конкретному підрозділі; чисельністю осіб рядового і начальницького складу, держслужбовців та працівників, які опанували сумісні професії, і їхньою соціальною активністю; співвідношення чисельності чоловіків і жінок на рі- 
зних посадах і у професійних групах.

- якість розстановки кадрів за посадами і спеціальностями.

- ступінь відповідності особи рядового чи начальницького складу, держслужбовця, працівника до вимог робочого місця.

- тривалість використання особи рядового чи начальницького складу, держслужбовця, працівника на одній посаді.

Основним аналітичним способом визначення якісного складу персоналу системи ДСНС є баланс порівняльних даних, порівняння штатної потреби осіб рядового та начальницького складу, держслужбовців, працівників для виконання своїх функціональних обов'язків, завдань за призначенням за чисельністю, професіями, кваліфікацією, освітою і їх наявністю.

2. Рівень плинності кадрів системи ДСНС (результат звільнення одних держслужбовців, осіб рядового i начальницького складу, працівників i прийняття інших на роботу / на службу в систему ДСНС). Як правило плинність кадрів в системі ДСНС включає певні фінансові витрати. Найпоширеніші причини звільнень осіб рядового та начальницького складу, держслужбовців та працівників умовно поділяються на три основні групи:

- пов'язані з сімейно-побутовими обставинами;

- 3 незадоволеністю умовами праці та побуту (працівники);

- 3 порушеннями трудової дисципліни (держслужбовці, працівники) чи дисциплінарного статуту (особи рядового та начальницького складу).

3. Результативність служби/праці в системі ДСНС (соціальноекономічна категорія, яка визначає рівень досягнення ДСНС своєї цілі, співвіднесеної з рівнем раціональності витрачання використаних при цьому сил та засобів служби цивільного захисту (ресурсів). Іншими словами - це співвідношення між результативністю служби/праці та величиною витрат (у тому числі ступенем раціонального використання ресурсів), що виражається у досягненні максимального ефекту за мінімальних витрат).

Враховуючи вищезазначене слід сказати, що ефективність є найважливішим елементом саморозвитку офіцера, держслужбовця чи працівника, розвитку підприємства, установи, організації, діяльність яких пов'язана з організацією і здійсненням заходів цивільного захисту зокрема та запорукою життєдіяльності сучасного суспільства вцілому. Якість кадрової політики будь-якої установи, зокрема ДСНС, залежить насамперед від старанності добору і розстановки організаторів службової діяльності. Організаційна робота належить до числа таких видів людської діяльності, які вимагають специфічних особистих якостей, що роблять особу професійно придатною до роботи керівника. Під професійною придатністю розуміється міра відповідності того або іншого кандидата на заміщення керівної посади, певній сумі вимог, установлених для цієї посади.

Наказом Міністерства внутрішніх справ України (далі - МВС) «Про затвердження Порядку формування кадрового резерву для призначення на вищі посади осіб середнього і старшого начальницького складу служби ци- 
вільного захисту» від 29 жовтня 2014 року № 1153 [4] визначено механізм формування кадрового резерву для призначення на вищі посади осіб середнього і старшого начальницького складу в органах і підрозділах цивільного захисту.

Згідно з вищезазначеним нормативно-правовим актом, кадровим резервом вважається група спеціально відібраних та затверджених у встановленому порядком осіб середнього і старшого начальницького складу служби цивільного захисту (далі - особи середнього і старшого начальницького складу) з числа найбільш перспективних, професійно підготовлених та ініціативних осіб, які мають організаторські здібності і які після практичної перевірки та вивчення, а також відповідної цілеспрямованої підготовки можуть розглядатися як кандидати для призначення на вищі посади.

Основним змістом роботи з кадровим резервом $є$ :

- постійне, всебічне та цілеспрямоване вивчення осіб середнього i старшого начальницького складу, перспектив подальшого проходження ними служби з урахуванням досягнутих результатів служби, стану дисципліни i висновків атестаційних комісій, їх морально-етичних, професійних, ділових, особистих якостей та досвіду практичної роботи;

- своєчасне прийняття рішень щодо осіб середнього і старшого начальницького складу, які підвищили кваліфікацію, пройшли перепідготовку і за результатами атестування рекомендовані до призначення на вищу посаду.

Головним елементом усієї системи управління підприємства, установи, організації, діяльність яких пов'язана з організацією і здійсненням заходів цивільного захисту є персонал. Здатність персоналу одночасно виступати в ролі об'єкта й суб'єкта управління є головною специфічною особливістю управління персоналом.

Під управлінням персоналом розуміється процес планування, підбору, підготовки, оцінювання та безперервного навчання працівників, спрямований на раціональне використання їх та підвищення продуктивності праці.

Організація роботи 3 кадровим резервом включає три взаємопов'язані між собою частини: формування кадрового резерву; безпосередня робота 3 особами середнього і старшого начальницького складу, зарахованими до кадрового резерву, організація їх навчання та стажування; щорічний аналіз складу кадрового резерву, ефективності роботи з ним, оцінювання рівня підготовленості осіб середнього і старшого начальницького складу, зарахованих до кадрового резерву.

Предметом управління персоналом є вивчення відносин осіб середнього і старшого начальницького складу, держслужбовців та працівників у процесі несення служби з метою найбільш повного та ефективного використання їхнього потенціалу в умовах функціонування служби цивільного захисту.

Головна мета управління персоналом - поєднання ефективного навчання персоналу, підвищення кваліфікації та трудової мотивації спрямованих на розвиток здібностей працівників заради розв'язання завдань, що стоять 
перед установою та її підрозділами.

Поняття кадри системи ДСНС включає штатний склад підготовлених, кваліфікованих працівників підприємств, установ, організацій, діяльність яких пов'язана з організацією і здійсненням заходів цивільного захисту. Процес управління кадрами ДСНС передбачає, по-перше, визначення мети та основних напрямів роботи з кадрами і постійне вдосконалення системи кадрової роботи на підприємстві, установі, організації, діяльність яких пов'язана з організацією і здійсненням заходів цивільного захисту; по-друге, визначення засобів, форм і методів здійснення поставленої мети, організацію роботи, служби з виконання прийнятих рішень, координацію і контроль виконання визначених заходів.

Відповідно до Постанови Кабінету Міністрів України № 1052 від 16 грудня 2015 року «Про затвердження Положення Про Державну службу України $з$ надзвичайних ситуацій» ДСНС є центральним органом виконавчої влади, діяльність якого спрямовується і координується Кабінетом Міністрів України через Міністра внутрішніх справ і який реалізує державну політику у сфері цивільного захисту, захисту населення і територій від надзвичайних ситуацій та запобігання їх виникненню, ліквідації наслідків надзвичайних ситуацій, рятувальної справи, гасіння пожеж, пожежної та техногенної безпеки, діяльності аварійно-рятувальних служб, а також гідрометеорологічної діяльності [2].

Основними завданнями ДСНС є:

- реалізація державної політики у сфері цивільного захисту, захисту населення і територій від надзвичайних ситуацій, запобігання їх виникненню, ліквідації наслідків надзвичайних ситуацій, рятувальної справи, гасіння пожеж, пожежної та техногенної безпеки, діяльності аварійно-рятувальних служб, а також гідрометеорологічної діяльності;

- здійснення державного нагляду (контролю) за додержанням і виконанням вимог законодавства у сфері цивільного захисту, пожежної та техногенної безпеки, діяльності аварійно-рятувальних служб;

- внесення на розгляд Міністра внутрішніх справ пропозицій щодо забезпечення формування державної політики у зазначених сферах;

- реалізація в межах повноважень, передбачених законом, державної політики у сфері волонтерської діяльності.

Стосовно кадрової політики ДСНС відповідно до покладених на неї завдань:

- здійснює підготовку, перепідготовку та підвищення кваліфікації осіб рядового і начальницького складу служби цивільного захисту, державних службовців і працівників апарату ДСНС, а також осіб, включених до кадрового резерву;

- здійснює функції з організації та навчально-методичного забезпечення навчання (підвищення кваліфікації за цільовим призначенням) керівних кадрів і фахівців центральних та місцевих органів виконавчої влади, органів 
місцевого самоврядування, підприємств, установ, організацій, діяльність яких пов’язана з організацією і здійсненням заходів цивільного захисту.

ДСНС з метою організації своєї діяльності здійснює добір кадрів в апарат ДСНС та на керівні посади в іï територіальні органи, на підприємства, в установи, організації, що належать до сфери іiі управління, формує кадровий резерв на відповідні посади, організовує роботу з підготовки, перепідготовки та підвищення кваліфікації державних службовців і працівників апарату ДСНС.

Голова ДСНС забезпечує формування в установленому порядку кадрового резерву ДСНС, організацію підготовки, перепідготовки та підвищення кваліфікації осіб рядового і начальницького складу служби цивільного захисту, державних службовців і працівників ДСНС та осіб, включених до кадрового резерву.

Головним підрозділом, що відповідає за кадрову політику системи ДСНС є Департамент персоналу, основним завданням якого є забезпечення реалізації державної політики у сферах цивільного захисту і державної служби з питань управління персоналом (кадрами) ДСНС України [5].

За умов постіндустріального суспільства, розвитку інтелектуальних, наукоємних технологій відбувається зростання ролі людського фактору в економічній діяльності. Зважаючи на це, засобом досягнення високого рівня конкурентоспроможності будь-якого підприємства, установи чи організації в тому числі тих, чия діяльність пов'язана з організацією і здійсненням заходів цивільного захисту $є$ пошук прихованих резервів підвищення ефективності діяльності персоналу, що реалізується, перш за все, через налагодження системи його безперервного розвитку. У свою чергу, управління розвитком стає центральною ланкою менеджменту та провідним чинником успіху суб'єктів господарювання як на вітчизняному так і на світовому ринках. На мою думку, ефективне впровадження безперервного розвитку персоналу у повсякденну діяльність вітчизняних суб'єктів господарювання можливе лише за умови попереднього створення грунтовного теоретичного та методичного забезпечення даного процесу.

Найважливішою складовою розвитку персоналу, кодрової політики в системі ДСНС, на мою думку, є професійне навчання осіб рядового та начальницького складу служби цивільного захисту, держслужбовців, працівників, адже саме воно створює умови для самореалізації особистості, збереження і раціонального використання людських ресурсів штату у процесі досягнення стратегічної мети ДСНС України - мінімізація потенційної шкоди від надзвичайних ситуацій, їх оперативна ліквідація та, перш за все, збереження життя людини.

Під професійним навчанням осіб рядового та начальницького складу служби цивільного захисту, держслужбовців, працівників слід розуміти цілеспрямований процес набуття працівниками системи ДСНС професійних знань, умінь та навичок, необхідних для виконання певних видів робіт, за- 
вдань за призначенням з метою підвищення продуктивності праці та ефективності роботи системи ДСНС. Професійне навчання персоналу може здійснюватися із використанням різноманітних його форм та методів.

Постановою Кабінету Міністрів України «Про затвердження Порядку проведення навчання керівного складу та фахівців, діяльність яких пов'язана з організацією і здійсненням заходів 3 питань цивільного захисту» від 23 жовтня 2013 року № 819 визначено механізм проведення навчання керівного складу та фахівців, діяльність яких пов'язана 3 організацією і здійсненням заходів з питань цивільного захисту [3].

Постановою передбачено, що навчання керівного складу і фахівців для потреб центральних органів виконавчої влади здійснює Інститут державного управління та наукових досліджень з цивільного захисту. Для навчання керівного складу та фахівців, діяльність яких пов'язана з організацією і здійсненням заходів 3 питань цивільного захисту, ДСНС разом 3 місцевими держадміністраціями та органами місцевого самоврядування утворює навчально-методичні центри сфери цивільного захисту, до яких належать навчально-методичні центри цивільного захисту та безпеки життєдіяльності та територіальні курси цивільного захисту та безпеки життєдіяльності.

ДСНС $з$ певною періодичністю спільно з іншими, в тому числі, міжнародними силовими структурами (НАТО, СБУ, Нацгвардія, Нацполіція, Збройні сили України та ін.) проводять спільні навчання з метою удосконалення професійних здібностей офіцерів всіх силових структур.

Так, впродовж 21-25 вересня 2015 року на Львівщині відбулися спільні міжнародні навчання ДСНС України та НАТО із запобігання та ліквідації наслідків надзвичайних ситуацій UKRAINE-2015. Навчання відбулися в рамках річної національної програми співробітництва Україна - НАТО на 2015 рік, з метою подальшого поглиблення співробітництва між Державною службою України з надзвичайних ситуацій та Північноатлантичним альянсом у сфері цивільного захисту населення, відпрацювання порядку взаємодії під час запобігання та реагування на надзвичайні ситуації природного і техногенного характеру. 15 вересня 2017 року в Київській області відбулися планові спецнавчання підрозділів ДСНС "Київське море - 2017" 3 демонстрацією можливостей пошуково-рятувальних сил під час проведення рятувальної операції на водному об'єкті. Такі навчання дають змогу підвищити свій професійний рівень осіб рядового та начальницького складу служби цивільного захисту а також виявити певні прогалини у професійних навиках та вжити заходів для їх усунення.

Отже, з метою досягнення максимальної ефективності професійного навчання персоналу системи ДСНС України їі кадрова політика $є$ розвиненою та всеохоплюючою, однак в процесі управління та розвитку персоналу слід приділяти увагу на освітньо-кваліфікаційний рівень кандидатів на службу: чи саме та чи інша кваліфікація відповідає потенційній посаді. Також при підготовці кадрів, розвитку та удосконаленню їх умінь та навичок не 
варто обмежуватися застосуванням окремих його форм чи методів, а використовувати їх системно у поєднанні та взаємодії. Це дозволить досягти високої якості людського капіталу в службі цивільного захисту та, як наслідок, забезпечить високий рівень підготовки кадрів до дій за призначенням, виконання своїх функціональних обов'язків на найвищому рівні.

\section{Список використаних джерел:}

1. Про вищу освіту: Закон України від 01.07.2014 № 1556-VII. URL: http://zakon2.rada.gov.ua/laws/show/1556-18.

2. Про затвердження Положення про Державну службу України з надзвичайних ситуацій : постанова Кабінету Міністрів України від 16.12.2015 № 1052. URL: http://www.kmu.gov.ua/control/uk/cardnpd?docid=248721664.

3. Про затвердження Порядку проведення навчання керівного складу та фахівців, діяльність яких пов'язана з організацією і здійсненням заходів з питань цивільного захисту : постанова Кабінету Міністрів України від 23 жовтня 2013 р. № 819 .

4. Про затвердження Порядку формування кадрового резерву для призначення на вищі посади осіб середнього і старшого начальницького складу служби цивільного захисту. Наказ МВС України від 29 жовтня 2014 року № 1153.

5. ДСНС України. URL: https://www.dsns.gov.ua/ua/Departamentpersonalu.html.

\section{Reference:}

1. On higher education [Pro vyshchu osvitu: Zakon Ukrayiny]: Law of Ukraine of 01.07.2014 № 1556-VII. URL: http://zakon2.rada.gov.ua/laws/show/1556-18.

2. On approval of the Regulation on the Civil Service of Ukraine for Emergencies: Resolution of the Cabinet of Ministers of Ukraine of 16.12.2015 № 1052 [Pro zatverdzhennya Polozhennya pro Derzhavnu sluzhbu Ukrayiny z nadzvychaynykh sytuatsiy : postanova Kabinetu Ministriv Ukrayiny]. URL: http://www.kmu.gov.ua/control/uk/cardnpd?docid=248721664.

3. On approval of the Procedure for training of management and specialists whose activities are related to the organization and implementation of measures on civil protection: Resolution of the Cabinet of Ministers of Ukraine of October 23, 2013 № 819 [Pro zatverdzhennya Poryadku provedennya navchannya kerivnoho skladu ta fakhivtsiv, diyalnist yakykh povyazana $\mathrm{z}$ orhanizatsiyeyu i zdiysnennyam zakhodiv z pytan tsyvilnoho zakhystu : postanova Kabinetu Ministriv Ukrayiny].

4. On approval of the Procedure for formation of the personnel reserve for appointment to senior positions of persons of middle and senior management of the civil defense service. Order of the Ministry of Internal Affairs of Ukraine of October 29, 2014 № 1153 [Pro zatverdzhennya Poryadku formuvannya kadrovoho rezervu dlya pryznachennya na vyshchi posady osib serednoho i starshoho nachalnytskoho skladu sluzhby tsyvilnoho zakhystu. Nakaz MVS Ukrayiny].

5. State Service of Ukraine for Emergencies [Derzhavna sluzhba Ukrayiny z nadzvychaynykh sytuatsiy]. URL: https://www.dsns.gov.ua/en/Departamentpersonalu.html. 